LWSA

Local Wisdom, Social, and Arts

PAPER - OPEN ACCESS

\title{
Peran Penyuluh dan Sikap Petani dalam Pengembangan Kelompok di Kecamatan Barusjahe
}

\author{
Author \\ : Ray Damen Sitepu \\ DOI \\ : 10.32734/lwsa.v1i1.177 \\ Electronic ISSN \\ : 2654-7058 \\ Print ISSN \\ : 2654-7066
}

Volume 1 Issue 1 - 2018 TALENTA Conference Series: Local Wisdom, Social and Arts

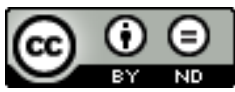

This work is licensed under a Creative Commons Attribution-NoDerivatives 4.0 International License.

Published under licence by TALENTA Publisher, Universitas Sumatera Utara
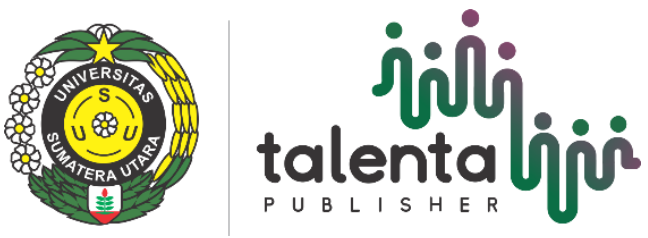


\title{
inili talenta ịio TALENTA Conference Series \\ P U B L I S H E R Available online at https://talentaconfseries.usu.ac.id \\ Peran Penyuluh dan Sikap Petani dalam Pengembangan Kelompok di Kecamatan Barusjahe
}

\author{
Ray Damen Sitepu ${ }^{\mathrm{a}}$, Diana Chalil ${ }^{\mathrm{a}}$ \\ ${ }^{a}$ Fakultas Pertanian, Universitas Sumatera Utara, Medan, 20155, Indonesia \\ damenray@gmail.com
}

\begin{abstract}
Abstrak
Kabupaten Karo merupakan sentra produksi tanaman hortikultura di Sumatera Utara dengan jumlah kelompok tani yang mencapai 3.003 kelompok. Namun hanya 44 kelompok yang berada pada kelas "Lanjutan" sementara sisanya berada di kelas "Pemula". Untuk menganalisis kondisi tersebut, dilakukan penelitian di Kecamatan Barusjahe, sebab daerah tersebut memiliki perkembangan kelompok tani yang paling baik (Bapeluh Kabupaten Karo, 2014). Data diperoleh dari penyuluh dan kelompok tani yang ditentukan dengan metode sensus dan purposive sampling. Selanjutnya data diolah dengan menggunakan metode skoring terhadap 49 indikator untuk menentukan peran penyuluh dan 20 pernyataan positif dan negatif untuk menentukan sikap anggota kelompok tani terhadap peran penyuluh. Hasil penelitian menunjukkan bahwa total skor peran penyuluh adalah sebesar 114,53 dan termasuk dalam kategori "sedang", dan 72,22\% anggota kelompok tani bersikap positif terhadap peran penyuluh pertanian tersebut. Kondisi tersebut merupakan peluang untuk pengembangan kelompok tani di Kecamatan Barusjahe, namun perlu perbaikan dalam beberapa hambatan seperti kesadaran pengurus dan anggota kelompok, partisipasi anggota kelompok, perencanaan dan pelaksanaan program yang memiliki komoditi berbeda dan areal lahan yang tidak pada satu hamparan, jumlah tenaga penyuluh, kelengkapan dan kesesuaian sarana dan prasarana yang dimiliki. Diharapkan dengan perbaikan hambatan tersebut kelompok tani di Kecamatan Barusjahe dapat mencapai tingkat kelas yang lebih tinggi.
\end{abstract}

Kata Kunci : Peran Penyuluh; Pengembangan Kelompok Tani; Sikap Petani

\section{Latar belakang}

Kelompok tani merupakan salah satu sarana paling penting dalam pengembangan pengetahuan serta produktivitas petani. Hal tersebut telah disadari oleh petani di Kecamatan Barusjahe, yang dapat dilihat dari jumlah kelompok tani yang mencapai 247 kelompok dengan total anggota 6.529 petani. Namun perkembangan kualitas kelompok tani masih rendah karena hanya 7 kelompok tani berada di kelas lanjutan, dan sisanya di kelas pemula (Bapeluh Kabupaten Karo, 2014). Salah satu alternatif solusi yang dapat digunakan adalah dengan meningkatkan peran penyuluh pertanian. Namun perlu ada kajian empiris untuk mengetahui bagaimana sesungguhnya peran penyuluh pertanian dalam pengembangan kelompok tani serta sikap petani terhadap peran penyuluh khususnya di Kecamatan Barusjahe.

\section{Metode penelitian}

Penelitian dilakukan di Kecamatan Barusjahe, yang termasuk salah satu daerah dengan jumlah kelompok tani terbanyak dengan tingkat perkembangan kelas kelompok tani yang paling baik dibandingkan kecamatan lain di 
Kabupaten Karo. Unit sampling yang diambil adalah penyuluh pertanian lapangan dan pengurus kelompok tani. Sampel penyuluh ditentukan secara sensus dengan total 13 orang. Sampel pengurus kelompok tani ditentukan dengan purposive (sengaja) dimana terdapat 9 kelompok tani yang memenuhi kriteria a) aktif melaksanakan kegiatan kelompok tani; b) kelompok tani menyelenggarakan demplot; c) pimpinan formal aktif; d) memiliki ad/art; e) mampu memberikan dan membuktikan informasi yang dibutuhkan peneliti.

Pengembangan kelompok tani diukur dengan melihat aspek-aspek manajerial yang telah dilaksanakan kelompok tani, yaitu perencanaan kegiatan, pengorganisasian kegiatan, pelaksanaan kegiatan, serta pengendalian dan pelaporan kegiatan. Penilaian perkembangan kelompok tani dilakukan oleh penyuluh untuk kemudian ditentukan kelas kelompok taninya (pemula, lanjutan, madya, utama) oleh Badan Pelaksana Penyuluhan. Peran penyuluh diukur dengan menganalisis keterlibatan penyuluh pada aspek-aspek manajerial yang terdiri dari 49 indikator dengan total skor maksimal 149 dan minimal 49. Peran dibedakan atas 3 kategori yaitu rendah, sedang, dan tinggi dengan rentang masing-masing 79-82, 83-116, dan 17-149. Sikap petani terhadap peran penyuluh pertanian diukur dengan skala Likert. Skor untuk masing-masing pernyataan positif adalah Sangat Setuju $=5$, Setuju $=4$, Rata-Rata $=$ 3, Tidak Setuju $=2$, dan Sangat Tidak Setuju $=1$, sementara untuk pernyataan negatif adalah Sangat Setuju $=1$, Setuju $=2$, Rata- rata $=3$, Tidak Setuju $=4$, dan Sangat Tidak Setuju $=5$. Skor tersebut digunakan untuk mendapatkan skor standar dengan rumus :

$\mathrm{T}=50+10\left(\frac{\mathrm{x}-\mathrm{x}}{5}\right)$

dimana : Skor Standar; $X$ : Skor responden; $\bar{X}$ : Rata-rata skor kelompok; S : Deviasi Standar Kelompok. Jika T > 50, maka sikap positif dan jika $T \leq 50$, maka sikap negatif.

\section{Hasil dan pembahasan}

Dari data skor untuk peran penyuluh, diperoleh total skor peran penyuluh sebesar 114,53 dengan rata-rata skor 65,60 yang termasuk dalam kategori "sedang". Untuk perencanaan kegiatan, pengorganisasian kegiatan dan pelaksanaan kegiatan kelompok tani, peranan penyuluh pertanian Kecamatan Barusjahe adalah "sedang", dengan rata-rata skor masing-masing adalah 65,$69 ; 62,18 ; 64,91$. Skor peran penyuluh pertanian paling rendah adalah pada pengorganisasian kegiatan. Hal tersebut disebabkan karena kurangnya perhatian penyuluh dalam meregenerasi pengurus kelompok tani dan kurangnya campur tangan penyuluh dalam menentukan aturan tertulis kelompok tani. Kesimpulan tersebut dilihat dari pengurus kelompok tani yang tetap sama sejak awal pembentukan kelompok hingga saat ini, dimana sebagian besar kelompok tani Kecamatan Barusjahe telah terbentuk di tahun 2007-2009. Aturan tertulis yang ada pun belum diperbaharui sejak terbentuknya kelompok tani. Belum adanya motivasi anggota kelompok tani untuk menjadi pengurus menjadi hambatan bagi penyuluh untuk mengganti pengurus lama yang kinerjanya belum maksimal. Sedangkan dalam pengendalian dan pelaporan kegiatan kelompok tani, peran penyuluh pertanian di Kecamatan Barusjahe dikategorikan "tinggi" dengan skor 69,23. Hal ini dilihat dari kinerja penyuluh dalam memantau hasil dari kegiatan-kegiatan yang dilakukan kelompok tani dengan bantuan pemerintah. Setiap bulan penyuluh melakukan kunjungan lapangan untuk melihat perkembangan demplot maupun bibit-bibit bantuan yang diberikan pemerintah. Penyuluh juga giat membimbing pengurus kelompok tani untuk membuat laporan kegiatan yang dilakukan oleh kelompoknya. Tak jarang pula penyuluh bersama pengurus mengerjakan laporan kegiatan bilamana sudah mencapai batas waktu terakhir pengumpulan laporan. Kurangnya pengetahuan dan infrastruktur kelompok tani dalam menyusun laporan kegiatan menjadi kendala bagi pengurus, sehingga penyuluh harus turun tangan mengerjakan laporan kegiatan kelompok, karena laporan kegiatan kelompok tani juga dibutuhkan oleh para penyuluh untuk menyusun evaluasi programa penyuluhan pertanian.

Kerjasama yang baik tersebut dapat berjalan dengan lancar karena sikap anggota kelompok tani terhadap peran penyuluh pertanian yang cukup baik. Hasil perhitungan menggunakan skala Likert menunjukkan bahwa dari 15 anggota kelompok tani sampel, sebanyak 13 orang $(72,22 \%)$ mempunyai sikap positif sementara 5 orang $(27,88 \%)$ mempunyai sikap negatif. Sehingga dapat diambil kesimpulan bahwa anggota kelompok tani sudah menerima dengan baik keberadaan penyuluh dalam menjalankan perannya. Sikap petani positif karena sebagian besar aspirasi petani didengar dan diupayakan oleh penyuluh. Penyuluh pun melaksanakan kunjungan lapangan secara rutin 
kepada petani. Selain itu penyuluh merupakan sumber informasi dalam hal bantuan dari pemerintah untuk petani, sehingga kehadiran penyuluh diharapkan oleh petani. Namun sikap anggota kelompok tani tersebut belum dibarengi dengan partisipasi anggota kelompok tani untuk melakukan kegiatan kelompok seperti pertemuan kelompok tani, kelas belajar dan lain sebagainya. Motivasi terbesar petani menjadi anggota kelompok tani adalah untuk mendapatkan bantuan, sehingga petani hanya mau hadir dalam kegiatan kelompok tani yang bersifat sosialisasi bantuan baik dari pemerintah maupun swasta. Petani Kecamatan Barusjahe juga merasa pengalaman mereka dalam bertani lebih baik dibandingkan materi penyuluhan yang diberikan penyuluh dalam kelas belajar, sehingga motivasi petani rendah dalam mengikuti kelas belajar maupun kegiatan kelompok tani lainnya.

Dalam melaksanakan perannya, penyuluh di Kecamatan Barusjahe mengalami beberapa hambatan yang menyebabkan perannya tidak maksimal, antara lain adalah kesadaran pengurus dan anggota kelompok tani masih rendah dalam mengembangkan kelompok taninya, serta anggota kelompok tani sulit untuk dikumpulkan karena masih banyak anggota kelompok tani yang belum merasakan manfaat dari kelompok tani. Kedua hambatan tersebut disebabkan oleh motivasi sebagian besar pengurus maupun anggota kelompok tani yang hanya untuk mendapatkan bantuan. Sementara bantuan dari pemerintah sifatnya terbatas, dan tidak untuk seluruh kelompok tani yang ada di Kecamatan Barusjahe. Akibatnya, bagi kelompok yang belum mendapat bantuan, anggotanya merasa bahwa tidak ada manfaat bergabung dengan kelompok tani.

Hambatan lainnya adalah jumlah tenaga penyuluh yang kurang untuk membimbing seluruh kelompok tani yang ada di Kecamatan Barusjahe. Sarana dan prasarana yang dimiliki penyuluh juga belum sesuai dengan jumlah dan jenis yang dibutuhkan. Misalnya, untuk peralatan Balai Penyuluhan Pertanian Kecamatan Barusjahe belum terdapat komputer maupun printer untuk mempermudah kinerja penyuluh untuk kegiatan bersifat administratif. Di samping itu juga sebagian besar penyuluh masih belum mendapatkan kendaraan dinas.

Hambatan terakhir adalah belum terlaksananya kembali penilaian kemampuan kelompok tani dari Dinas Pertanian, padahal beberapa kelompok tani sudah melakukan beberapa perbaikan yang dinilai penyuluh sudah dapat berada pada kelas "Lanjutan."

\section{Kesimpulan}

Di Kecamatan Barusjahe, penyuluh sudah cukup baik berperan dalam pengembangan kelompok tani, namun belum optimal. Sikap anggota kelompok tani terhadap peran penyuluh juga "positif". Kondisi tersebut dapat memberikan peluang bagi kelompok tani di Kecamatan Barusjahe untuk dikembangkan menjadi tingkat kelas yang lebih tinggi. Namun sebagian besar kelompok tani tersebut masih berada dalam tingkat pemula karena beberapa hambatan seperti kurangnya motivasi anggota. Untuk mengatasi hambatan tersebut penyuluh perlu menanamkan kembali bahwa sebenarnya kelompok tani dibentuk adalah sebagai sarana musyawarah dan gotong royong untuk memecahkan permasalahan- permasalahan usaha tani anggota kelompok bukan hanya untuk mencari bantuan. Selain itu, kerjasama dengan kelompok tani pada kelas "madya" atau "utama" untuk bertukar pikiran maupun memberikan penyuluhan agar memotivasi kelompok tani di Kecamatan Barusjahe untuk mengembangkan kelompok taninya. Diharapkan jika hambatan tersebut dapat diatasi maka kelompok tani tersebut dapat mencapai tingkat kelas yang lebih tinggi.

\section{References}

[1] Badan Penyuluhan dan Pengembangan SDM Pertanian. (2014). Rencana strategis tahun 2014-2018. Kementrian Pertanian. Jakarta.

[2] Departemen Pertanian . (2000). Pedoman monitoring dan evaluasi penyuluhan pertanian. Departemen Pertanian Pusat Penyuluhan Pertanian. Jakarta

[3] Setiana, L. (2005). Teknik penyuluhan dan pemberdayaan masyarakat. Ghalia Indonesia. Bogor Suhardiyono, L. (1992). Petunjuk Bagi Penyuluhan Pertanian. Erlangga. Jakarta.

[4] Undang-Undang No 16 Tahun 2006 tentang Sistem Penyuluhan Pertanian, Perikanan, dan Kehutanan. Jakarta 